\title{
TRANSFER AND VIABILITY OF ONE-CELL OVA IN SHEEP*
}

\author{
G. O. WOODY $\dagger$ AND L. G. ULBERG \\ Department of Animal Science, North Carolina State College, \\ Raleigh, North Carolina, U.S.A.
}

(Received 14th September 1962)

\begin{abstract}
Summary. Attempts to obtain fertilization of sheep ova recovered from follicles and deposited in the oviducts of the same ewes were unsuccessful. The recovery and transfer of postovulatory one-cell ova was successful if the paired ewes were closely synchronized as to the end of oestrus. Fertilization apparently was completed soon after the end of oestrus in mated ewes and ova from non-mated ewes were apparently still capable of normal fertilization and development at this time. Ova from non-mated ewes usually do not have corona cells present when recovered from the oviduct. Both fertilized and unfertilized ova appear to be able to withstand stress associated with a single transfer, but a second transfer greatly reduces the chances of a successful pregnancy.
\end{abstract}

\section{INTRODUCTION}

It has been shown by Alliston \& Ulberg (1961), using embryo transfer techniques, that embryos produced by ewes maintained at $90^{\circ} \mathrm{F}$ are irreversibly damaged by 3 days after mating, although the damage is not morphologically apparent. Dutt (1960) placed recently mated ewes in rooms heated to $90^{\circ} \mathrm{F}$ and found that pregnancy failure, due to high environmental temperatures, steadily decreased as the age of the embryo increased. These observations indicate that the potential young are most sensitive to damage at a very early stage in development, possibly even before fertilization, causing death at a later stage of development.

There are three stages in the reproductive process where this damage could occur: (1) the unfertilized ovum, (2) the spermatozoa after deposition in the ewe but before fertilization, and (3) the ovum after fertilization. The damage could also be cumulative in the three stages. This paper is the result of efforts to develop techniques for the study of unfertilized sheep ova in relation to causes of early embryonic death.

- Published with the approval of the Director of Research, North Carolina Experiment Station as paper No. 1496 of the Journal Series.

$\dagger$ NSF Co-operative Fellow. 


\section{MATERIALS AND METHODS}

Beginning in the late winter of 1960, and continuing through December 1961, approximately 100 grade Western Blackface ewes were used in an attempt to develop a technique for the recovery and transfer of unfertilized ova. Oestrus control in anoestrous and in some of the oestrous ewes was effected by fourteen daily subcutaneous injections of $10 \mathrm{mg}$ progesterone in oil followed by 750 i.u. (anoestrous ewes) or 500 i.u. (oestrous ewes) of pregnant mares' serum (PMS) $48 \mathrm{hr}$ after the last progesterone injection. Vasectomized or aproned rams were used twice daily for detection of oestrus. Oestrous ewes were isolated without feed or water and recovery of the ova was attempted 12 to $36 \mathrm{hr}$ later.

Ewes were anaesthetized lightly with sodium pentobarbital, a mid-ventral laparotomy was made, and the ova recovered. The ova were examined under a low power stereomicroscope $(\times 10$ to 60$)$ and then deposited into the infundibular end of the oviduct or into the uterine lumen by puncture of the uterine wall. Ewes not returning to heat were laparotomized 25 to 35 days later and pregnancy was determined by palpation of the uterus for an amnionic vesicle.

Where ova were recovered from the oviduct, the technique used was similar to that developed by Hunter, Adams \& Rowson (1955) and modified by Alliston \& Ulberg (1961). Polyethylene tubing was inserted about $1 \mathrm{~cm}$ into the infundibular end of the oviduct and held there by a wound clip applicator. The flushing solution was injected into the uterus and forced through the oviduct and tubing into a watchglass (Pl. 1, Fig. 1). Three different flushing solutions were used: (1) modified Krebs' solution (Lardy \& Phillips, 1943) for recovery from follicles, (2) $50 \%$ modified Krebs' solution and $50 \%$ homologous blood serum for recoveries from the oviduct the 1st year, and (3) $75 \%$ modified Krebs' solution and $25 \%$ serum from the mated ewe in the 2nd year of the postovulatory transfer.

Preovulatory ova were recovered from follicles (judged to be closest to the time of ovulation) of mated ewes 12 to $24 \mathrm{hr}$ after onset of heat. A sharpened glass tube or 15-gauge hypodermic needle, attached to a short length of polyethylene tubing, was used in recovering the ova. The point of the glass tube was inserted into the side of the follicle and the ovum was then collected by injecting the flushing solution into the follicle from the opposite side with a syringe and collecting the washings in a watchglass. On some occasions ova were recovered from small follicles and deposited in oviducts without other ova. Recovery from these small follicles was made by puncturing the follicle with a sharpened glass capillary tube drawn from 6-mm tubing and allowing capillary action to draw in the ovum. Ova were recovered for re-examination 24 to $48 \mathrm{hr}$ after the original deposition, examined for cleavage, and redeposited in the same oviduct, providing they were not degenerate. Control ewes for measuring inherent fertility were mated, the ova recovered from the oviducts approximately 3 days later and examined before deposition in the opposite uterine horn of the same ewe.

In the recovery and transfer of postovulatory unfertilized ova, the onset of 


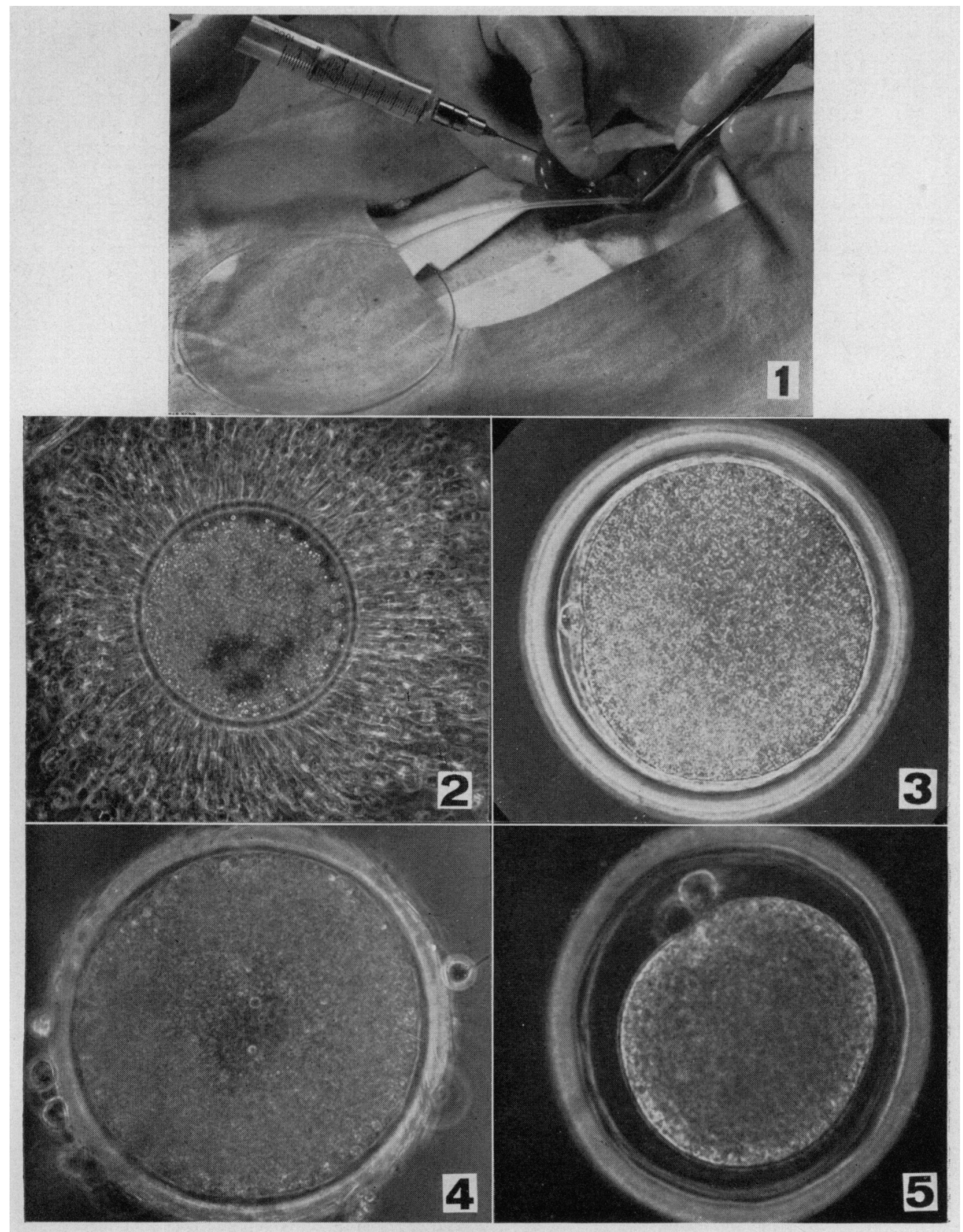

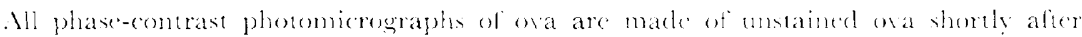
recovery and slightly compresied by a corrolip.

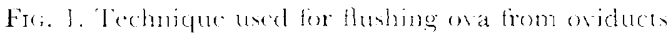

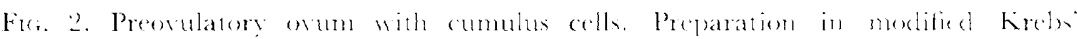
solution. 20)(1).

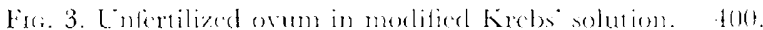

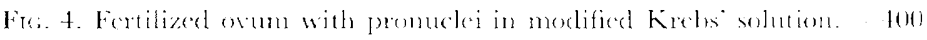

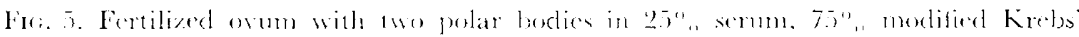
solutions. 200)

(Fining fr. 20)4 
oestrus was synchronized in pairs of ewes to within $12 \mathrm{hr}$ either by hormonal control or by natural synchronization. One ewe of each pair was mated, usually twice, before a transfer, and the transfer was attempted approximately 24 to 36 $\mathrm{hr}$ after onset of oestrus. Initially the time of transfer was arbitrarily selected (24 or $36 \mathrm{hr}$ after initiation of oestrus), while later the time of transfer depended upon synchronous end of heat. In the latter ewes the transfer was performed shortly after they were first found to be out of heat.

Since removal of the fertilized ovum was desired, reciprocal transfers were made, the mated ewe received the unfertilized ovum and the non-mated ewe the ovum from the mated ewe. Initially ova were recovered from the oviducts a second time 24 to $48 \mathrm{hr}$ later, examined for cleavage and redeposited. Later transfers did not include a second recovery. Control animals to measure inherent fertility included ewes in which the ova were transferred between animals approximately 3 days after mating and also ewes in which no transfers were performed.

\section{RESULTS}

PREOVULATORY OVA

Thirty-one ova were recovered from follicles and deposited in the oviducts of the ewes from which they originated. The ova were covered with corona radiata cells (Pl. 1, Fig. 2). Eight of these ova were examined 24 to $48 \mathrm{hr}$ later, but none had cleaved. Two of these, however, had two polar bodies $24 \mathrm{hr}$ after being deposited in the oviducts. No pregnancies resulted from transfers of follicular ova whether or not the second recovery was successful. These ewes were in anoestrus; however, three of seven control transfers (4- to 16-cell) resulted in pregnancies and all ova from control ewes were cleaving at the time of transfer.

\section{POSTOVULATORY OVA}

Since the transfer of preovulatory ova did not appear feasible, the transfer of postovulatory ova was undertaken next. Ova recovered from non-mated ewes normally were devoid of corona radiata cells and had one polar body present (Pl. 1, Fig. 3). Ova from mated ewes normally had two polar bodies (Pl. 1, Fig. 5), but occasionally only one was observed, indicating fertilization may not have occurred. Also, various rearrangements of cytoplasmic granules were observed in ova from mated ewes, probably indicating various stages of syngamy (Pl. 1, Fig. 4).

When the ova originally recovered from non-mated ewes were examined for cleavage (Table 1), a greater percentage of those recovered $24 \mathrm{hr}$ after the initial detection of oestrus were found to be cleaving $(67 \%)$ than were those originally recovered $36 \mathrm{hr}$ after the initial detection of oestrus $(60 \%)$. Conversely, when the ova originally recovered from mated ewes were examined, a greater percentage of those recovered $36 \mathrm{hr}$ after the initial detection of oestrus were cleaving $(67 \%)$ than were those originally recovered $24 \mathrm{hr}$ after initial detection of oestrus (33\%). One degenerating ovum, transferred from an unmated ewe at $36 \mathrm{hr}$, was found at cleavage check. The only pregnancy 
resulting from a transfer of an unfertilized ovum was in the 36-hr group. The only pregnancy resulting from an ovum transferred from a mated ewe was in the 36-hr group; however, the attempt to recover it for re-examination had failed.

Since the pregnancy rate was low, but an acceptable degree of fertilization (as indicated by cleavage) was obtained, a third group of transfers was performed without making the cleavage check. The previous results support the data of Green \& Winters (1935) and McKenzie \& Terrill (1937), who showed

TABLE 1

FATE OF OVA RECIPROGALLY TRANSFERRED AFTER EXAMINATION DURING TWO STAGES OF DEVELOPMENT

\begin{tabular}{|c|c|c|c|c|c|c|}
\hline & \multicolumn{3}{|c|}{ Ova from mated ewes } & \multicolumn{3}{|c|}{ Ova from non-mated ewes } \\
\hline & $24 h r^{*}$ & $36 h r^{*}$ & Total & $24 h r^{*}$ & $36 h r^{*}$ & Total \\
\hline $\begin{array}{l}\text { Transfers attempted } \\
\text { Ewes ovulated } \\
\text { Ova recovered } \\
\text { Recovered second }\end{array}$ & $\begin{array}{l}7 \\
4 \dagger \\
3\end{array}$ & $\begin{array}{l}6 \\
6 \\
6\end{array}$ & $\begin{array}{r}13 \\
10 \\
9\end{array}$ & $\begin{array}{l}8 \\
7 \dagger \\
5\end{array}$ & $\begin{array}{l}7 \\
7 \\
7\end{array}$ & $\begin{array}{l}15 \\
14 \\
12\end{array}$ \\
\hline $\begin{array}{l}\text { examinationt } \\
\text { Ova cleaving } \\
\text { Ewes pregnant }\end{array}$ & $\begin{array}{l}3 \\
1 \\
0\end{array}$ & $\begin{array}{l}3 \\
2 \\
1 \S\end{array}$ & $\begin{array}{l}6 \\
3 \\
1 \S\end{array}$ & $\begin{array}{l}3 \\
2 \\
0\end{array}$ & $\begin{array}{l}5 \\
3 \| \\
1\end{array}$ & $\begin{array}{l}8 \\
5 \\
1\end{array}$ \\
\hline
\end{tabular}

* Time of transfer after onset of oestrus.

† Ewes not ovulated at $24 \mathrm{hr}$ are also included in the 36-hr group.

I Twenty-four to $48 \mathrm{hr}$ after original recovery.

$\$$ Pregnancy from ovum not recovered the second time.

II Another ovum had fragmented into four large and four small 'cells'.

TABLE 2

INITIATION OF PREGNANCY FROM OVA RECIPROCALLY TRANSFERRED AT END OF OESTRUS

\begin{tabular}{l|c|c}
\hline \multirow{2}{*}{} & \multicolumn{2}{|c}{ Source of ova } \\
\cline { 2 - 3 } & Mated ewes & Non-mated ewes \\
\hline Transfers attempted & 13 & 13 \\
Ova recovered & 11 & 10 \\
Ewes pregnant & 4 & $4 *$ \\
\hline
\end{tabular}

* Does not include a probable degenerating embryo found at 30 days after mating in one ewe.

that ewes ovulate very close to the end of oestrus, so recoveries were then attempted after the synchronous end of oestrus. As shown in Table 2, 36\% of the ova (four out of eleven) transferred from mated ewes resulted in pregnancies and $40 \%$ of the ova (four out of ten) transferred from non-mated ewes resulted in pregnancies. A probable degenerating embryo was also found at 30 days in one ewe receiving an ovum from a non-mated ewe.

Two of seven ewes $(28 \cdot 6 \%)$ receiving 8- to 16-cell embryos (control transfers) were pregnant and a third had a probable degenerating embryo. Seven of seven non-transferred control ewes were pregnant. No reason can be given 
for the poor results with ewes receiving 8- to 16-cell embryos; the anoestrous control ewes of the preovulatory group of transfers had given better results (three out of seven pregnant).

Although the overall pregnancy rate seems low, the data include results obtained while the techniques were being developed. The results with the ova from mated ewes were particularly poor until the flushing medium was changed from $50 \%$ homologous serum and $50 \%$ modified Krebs' solution to $25 \%$ serum from the mated ewe and $75 \%$ modified Krebs' solution. Four pregnancies resulted from seven such transfers after the change in medium versus none out of four transfers before the change (excluding the data of Table 1). In the last group of transfers performed (included as part of Table 2) three of four ova from mated ewes resulted in pregnancies and two of three ova from non-mated ewes resulted in pregnancies.

\section{DISCUSSION}

The transfer of one-cell ova, especially unfertilized ova, presents problems not associated with the transfer of 8- to 16-cell embryos. Noyes (1952) obtained up to $40 \%$ successful transfer of preovulatory ova in rats if the first maturation division had occurred. Chang (1955) reported that preovulatory rabbit ova would mature in the oviducts or in dilute serum, but only one of thirty-nine such oocytes developed into a normal foetus. It is even more difficult, if not impossible at present, to determine the time of impending ovulation in sheep, with enough accuracy to obtain mature ova. Green \& Winters (1935) and McKenzie \& Terrill (1937) have shown that most ewes ovulate shortly before or close to the end of oestrus. However, the results obtained in this study were not encouraging for the transfer of preovulatory ova in sheep. Only two of eight ova recovered a second time gave any indication of being fertilized and no pregnancies occurred from a total of thirty-one preovulatory ova transferred. The data from the control ewes indicated that it was possible to obtain a satisfactory fertilization rate and a fair number of pregnancies at that time of year from this group of sheep. This is in accord with the data of Lopyrin, Loginova \& Karpov (1950 a, b) who indicated that they obtained poor results in transfers of preovulatory ova. Only one of forty-three ewes receiving a preovulatory ovum was reported as becoming pregnant whereas seven of fortysix ewes receiving 1- to 2-day 'zygotes' produced lambs.

After ovulation, unfertilized ova of various species are subject to ageing; pigs-Dzuik (1960) and Hancock (1961), ferrets-Chang (1950). Green \& Winters (1935) estimated the life of the unfertilized sheep ovum as less than $24 \mathrm{hr}$. Thibault \& Ortavant (1949) have shown that sheep ova may be artificially activated by cold shock. The data presented here indicate that unfertilized ova are probably most viable when recovered at $24 \mathrm{hr}$ after initiation of oestrus, but not all ewes have ovulated at this time and ova from mated ewes may not be fertilized at this time. If transfer is made at $36 \mathrm{hr}$ after initiation of oestrus, ageing of some ova appears to occur. However, if the transfers are made soon after the end of oestrus, without regard to the time, then an acceptable degree of success is obtained. 
It may be noted that unfertilized ova were devoid of corona radiata cells, indicating that the presence of spermatozoa was not necessary for the removal of these cells. It may also be noted that the transfer apparently imposes a stress on the reproductive process, since two transfers greatly lowered the chances for a successful pregnancy as compared to a single transfer.

Overall, the recovery rate of postovulatory ova was quite high; forty-two ova were recovered from fifty ewes with fifty-one corpora lutea for $82.4 \%$ recovery, which would indicate that ova enter the oviduct very soon after ovulation.

\section{ACKNOWLEDGMENTS}

This investigation was supported in part by a PHS Research Grant, RG-5458, from the Division of General Medical Sciences, Public Health Service. We are grateful to Dr C. W. Alliston for aid in collecting part of the data and to Mrs Jean Hall and Mrs Donna Johnston for assistance.

\section{REFERENCES}

ALListon, C. W. \& Ulberg, L. C. (1961) Early pregnancy loss in sheep at ambient temperatures of $70^{\circ}$ and $90^{\circ} \mathrm{F}$ as determined by embryo transfer. $\mathcal{F}$. Anim. Sci. 20, 608 .

Chang, M. C. (1950) Cleavage of unfertilized ova in immature ferrets. Anat. Rec. 108, 31.

Chang, M. C. (1955) The maturation of rabbit oocytes in culture and their maturation, activation, fertilization and subsequent development in the fallopian tubes. 7. exp. Zool. 128, 379.

Dutr, R. H. (1960) From 73rd Ann. Rept. Dir. Ky. agric. exp. Sta., p. 33.

DzuIK, P. (1960) Frequency of spontaneous fragmentation of ova in unbred gilts. Proc. Soc. exp. Biol., N.Y. 103, 91 .

Green, W. W. \& Winters, L. M. (1935) Studies on the physiology of reproduction in sheep. III. The time of ovulation and rate of sperm travel. Anat. Rec. $61,457$.

Hancock, J. L. (1961) Fertilization in the pig. 7. Reprod. Fertil. 2, 307.

Hunter, G. L., Adams, C. E. \& Rowson, L. E. (1955) Inter-breed ovum transfer in sheep. 7. agric. Sci. 46, 143.

LARdy, H. A. \& Phillips, P. H. (1943) Effects of $\mathrm{pH}$ and certain electrolytes on the metabolism of ejaculated spermatozoa. Amer. F. Physiol. 138, 741.

Lopyrin, A. I., Loginova, N. V. \& Karpov, P. L. (1950a) Experiment in interbreed transference of ova in sheep (translated title). Sovetsk. Zooteh. (1950) (8), 50. In Anim. Breed. Abstr. 18, 415 (1950).

Lopyrin, A. I., Loginova, N. V. \& Karpov, P. L. (1950b) Changes in the exterior of lambs as a result of interbreed embryonic transfer (translated title). Dokl. Akad. Nauk SSSR, 74, 1019. In Anim. Breed. Abstr. 19, 355 (1951).

McKenzie, F. F. \& Terrill, C. E. (1937) Estrus, ovulation and related phenomena in the ewe. Mo. agric. exp. Sta., Res. Bull. No. 264.

Noyes, R. W. (1952) Fertilization of follicular ova. Fertil. Steril. 3, 1.

Thibault, C. \& Ortayant, R. (1949) Parthenogenèse expérimentale chez la brebis. C.R. Acad. Sci., Paris, 228, 510. 